\title{
RISK MANAGEMENT OF MULTINATIONAL CORPORATIONS
}

\section{УПРАВЛІННЯ РИЗИКАМИ ТРАНСНАЦІОНАЛЬНИХ КОРПОРАЦЙ}

\author{
Natalia V. Kovalenko \\ kovalenko-nv@ukr.net \\ ORCID: 0000-0001-8011-1373 \\ Iryna V. Panasiuk \\ irapanasiuk15092000@gmail.com \\ ORCID: 0000-0001-7102-3558
}

\author{
Н. В. Коваленко, \\ канд. екон. наук, доцент
}

\section{І. В. Панасюк,}

студентка

\author{
National Aviation University, Kyiv \\ Національний авіаційний університет, м. Київ
}

\begin{abstract}
The article considers the risks that arise during the management of transnational corporations (TNCs), provides their classification and ways to overcome them. Today TNCs play an important role in the development of the state's economy. We increase Gross National Product (GNP) by attracting foreign investment and expanding our activities. In Ukraine the activities of TNCs are expanding every year.

Purpose. More and more of our national employees are involved in multinational companies, so we have set ourselves the goal of studying the risks they face.

Method. To achieve this goal we use empirical and theoretical methods, i.e. our article is theoretical, devoted to the theoretical study of the problem. This allows them to gain more knowledge, skills, experience, foreign practice. Workers fly on business trips to headquarters, work there for a while, make new connections and continue to work together. In addition to the fact that transnational corporations are a stimulus to development, they also have negative features: monopolization of markets; creating a threat to national economies, as it may impose conditions on competitors; increases the reduction of employees in the enterprise, due to the globalization of the labor market.

Results. We have identified the following main corporate risks: credit, liquidity, interest, market, operational, systemic, legal tax.

Scientific novelty. Described the causes of their occurrence. Investigated the number of TNCs as at 30/06/2020. Leading positions belong to the companies: SAUDI ARABIAN OIL, APPLE INC and MICROSOFT CORP. They listed the features of risk management measures used by TNCs in contrast to companies operating within the same national economy: risk reduction strategy, risk retention strategy and generally accepted strategies and methods, some of which are specific. Risk management at the level of a multinational corporation has both similarities and differences with management at the level of a regular company. Features of financial risks of TNCs are related to their interpretation, classification and methods used. The means of reducing the degree of risk include: risk avoidance, retention, risk transfer. Ways to reduce the degree of risk include: diversification, acquisition of additional information, limitation, insurance, hedging.

Practical importance. The responsibilities of managers are to choose the most appropriate solutions for the company. One of its main tasks is to assess the risk and minimize it.
\end{abstract}

Key words: transnational corporation; risk; corporate risk; competitiveness; Gross National Product; risk hedging; capitalization.

Анотація. У статті розглянуто ризики, які виникають під час управління транснаціональними корпораціями (ТНК), наведено їхню класифікацію та шляхи подолання. Сьогодні ТНК відіграють важливу роль у розвитку економіки держави. Оскільки залучаючи таким способом іноземні інвестиції та розширюючи діяльність, ми збільшуємо валовий національний продукт (ВНП). В Україні діяльність ТНК щороку розширюється.

Мета. Дедалі більше наших національних працівників залучено до діяльності мультинаціональних компаній, тому ми визначили для себе за мету дослідити ризики, з якими вони стикаються.

Методика. Для досягнення мети ми застосовуємо емпіричні та теоретичні методи, тобто стаття є теоретичною, присвячена теоретичному вивченню проблеми. Це надає змогу отримати більше знань, навичок, досвіду, закордонної практики. Робітники літають у відрядження в головні офіси, працюють там деякий час, заводять нові зв'язки та продовжують співпрацю на національному рівні. Крім того, що транснаціональні корпорації $\epsilon$ стимулом до розвитку, їм притаманні і негативні риси: монополізація ринків; створення загрози національним 
економікам, оскільки може висувати умови конкурентам; збільшує скорочення працівників на підприємстві шляхом глобалізації ринку трудових ресурсів. ТНК прагнуть постійно, як і всі інші компанії, залишатися конкурентоспроможними та утримувати свої позиції в умовах динамічного розвитку середовища функціонування. Результати. Ми виділили такі основні корпоративні ризики: кредитний, ліквідності, процентний, ринковий, операційний, системний, юридичний податковий.

Наукова новизна. Охарактеризували причини їх виникнення. Дослідили кількість ТНК станом на 30 червня 2020 року. Провідні позиції належать компаніям SAUDI ARABIAN OIL, APPLE INC та MICROSOFT CORP. Навели особливості управлінських заходів регулювання ризику, які використовує ТНК, на відміну від компаній, що діють у межах однієї національної економіки: стратегія зменшення ризику, стратегія утримання ризику й загальноприйняті стратегії та методи, деякі з яких є специфічними. Управління ризиками на рівні транснаціональної корпорації має як схожості, так і відмінності з управлінням на рівні звичайної компанії. Особливості фінансових ризиків ТНК пов'язані з їхньою інтерпретацією, класифікацією та застосовуваними методами. До засобів зниження ступеня ризику відносимо: уникнення ризику, утримання його, передачу ризику. До способів зниження ступеня ризику відносимо: диверсифікацію, придбання додаткової інформації, лімітування, страхування, хеджування.

Практична значимість. Обов'язки керівників полягають у виборі найбільш відповідних для компанії рішень. Одне з основних його завдань - оцінити ризик і звести його до мінімуму.

Ключові слова: транснаціональна корпорація; ризик; корпоративний ризик; конкурентоспроможність; валовий національний продукт; хеджування ризиків; капіталізація.

Діяльність транснаціональних корпорацій (далі - ТНК) є основною рушійною силою в умовах інтеграції та глобалізації світової економіки. Успішна інтеграція країни у світову спільноту передбачає формування механізму оптимальної взаємодії з усіма його елементами, перш за все $з$ транснаціональними корпораціями. Інвестування в ТНК розширюють економічну й виробну співпрацю як у розвинених, так і в країнах, що розвиваються, насамперед за допомогою міжнародної торгівлі.

Проєкт Кодексу поведінки транснаціональних корпорацій ТНК трактує як «підприємства, незалежно від країни їхнього походження та форми власності, зокрема приватні, державні або змішані підприємства, з підрозділами у двох чи більше країнах, незалежно від юридичної форми та сфери діяльності цих підрозділів, які функціонують відповідно до певної системи ухвалення рішень, що дає змогу провадити узгоджену політику та загальну стратегію через один або кілька центрів з ухвалення рішень, і в межах яких підрозділи пов'язані між собою відносинами власності або такими відносинами, у яких один або кілька 3 підрозділів може чи можуть суттєво впливати на діяльність інших, користуватися спільними знаннями та ресурсами й розподіляти відповідальність 3 іншими підрозділами» ${ }^{1}$.

\section{ПОСТАНОВКА ЗАДАЧІ}

Процес виникнення такого типу компаній пов'язаний із процесами глобалізації, інтернаціоналі-

${ }^{1}$ Friends of the Earth (1998). A History of Attempts to Regulate the Activities of Transnational Corporations: What Lessons can be Learned. Discussion Paper for a Working Conference: Toward a Progressive International Economy. Washington, DC (11) (PDF) Redefining Transnational Corporations.

${ }^{2}$ https://fortune.com/ зації, тобто зближення економік і співпраці, зокрема і юридичних осіб. Завдяки існуванню ТНК підприємства мають змогу ефективніше використовувати наявні ресурси, удосконалювати міжнародний поділ праці, тобто спрямовувати капітал туди, де в результаті буде вища рентабельність і попит на продукцію, нижчі податки (особливо актуальною є локація Кіпр) та дешевша робота сила (зокрема, в Україні вважаємо цей показник високим, що приваблює міжнародні компанії здійснювати діяльність в Україні та наймати українських працівників).

\section{АНАЛІЗ ОСТАННІХ ДОСЛІДЖЕНЬ І ПУБЛІКАЦІЙ}

Відповідно до рейтингу найбільших компаній світу Global 500 на основі виторгу компаній за фінансовий рік, що закінчився 31 березня 2019 року або до цієї дати, сукупний річний виторг 500 компаній становив 32,7 трлн дол., а прибуток - 2,15 трлн дол. .

Провідні позиції в компанії Walmart, яка $є$ найбільшою у світі роздрібною мережею (гіпермаркети, універсами, що продають продовольчі та промислові товари), штаб-квартира розташована на північному заході штату Арканзас у Бентонвілі, США. Обрана стратегія мережі, що орієнтується на максимальний асортимент і мінімальні, майже гуртові ціни, принесла прибуток розміром 6,6 млрд дол. і виторг у розмірі 514,4 млрд дол. Друге місце в рейтингу посідає Sinopec Group, китайська інтегрована енергетична й хімічна компанія, з виторгом у 414,6 млрд дол., прибутком у 5,8 млрд дол. I Royal Dutch Shell транснаціональна корпорація з головною штаб-квартирою в Гаазі. Основним бізнесом компанії є розвідка, видобування, переробка, транспортування та збут вуглеводнів, (нафти і природного газу), що дало змогу посісти третє місце з виторгом у 396,5 млрд дол. і прибутком 23,3 млрд дол. 


\section{ВІДОКРЕМЛЕННЯ НЕ ВИРІШЕНИХ РАНІШЕ ЧАСТИН ЗАГАЛЬНОЇ ПРОБЛЕМИ}

Транснаціональні корпорації підвищують рівень конкуренції як між підприємствами, так і на галузевому рівні, формують потребу в інноваціях, змінюючи технології та формуючи умови для пришвидшення розвитку науково-технічного прогресу. ТНК здійснюють низку найважливіших функцій у світовій економіці, які можна згрупувати за напрямами: створюють стимул для постійного розвитку науково-технічного прогресу, адже науково-технічний прогрес створює нововведення, нові технологічні розробки; створюють стимул до глобалізації світової економіки, залучаючи країни в міжнародні економічні відносини; стимулюють розвиток світового виробництва, що проявляється в створенні нових робочих місць, розвитку виробництва в країнах, у яких відкриваються філії ТНК, відповідно, це $\epsilon$ поштовхом до розвитку світової економіки; створює конкурентне середовище на ринку.

Крім того, що транснаціональні корпорації є стимулом до розвитку, їм притаманні й негативні риси: монополізація ринків; створення загрози національним економікам, оскільки можуть висувати умови конкурентам; збільшують скорочення працівників на підприємстві через глобалізацію ринку трудових ресурсів [1]. ТНК прагнуть постійно, як і всі інші компанії, залишатися конкурентоспроможними та утримувати свої позиції в умовах динамічного роз- витку середовища функціонування. Їхня діяльність, безумовно, пов'язана з низкою ризиків та потребою ухвалення рішень в умовах невизначеності.

\section{МЕТА ДОСЛІДЖЕННЯ}

Як ми раніше зазначили в анотації, метою дослідження $є$ охарактеризувати ризики ТНК та запропонувати шляхи їх уникнення.

\section{МЕТОДИ, ОБ'ЄКТ ТА ПРЕДМЕТ ДОСЛІДЖЕННЯ}

Об’єктом дослідження є ризики та їхні окремі види; предметом - сфера ризиків, що виникають у ТНК; до методів, що використовуємо, відносимо такі: емпіричний, теоретичний, дедукція, прогнозування.

\section{ОСНОВНИЙ МАТЕРІАЛ}

Розгляньмо основні види корпоративних ризиків, що пов'язані з діяльністю ТНК та згруповані в таблиці 1.

Сучасний розвиток товарного виробництва і сфери різних послуг характеризується створенням як багатогалузевих, так і спеціалізованих на конкретному виді діяльності ТНК.

Великі зарубіжні компанії витрачають значні гроші на аналіз і комп'ютерне моделювання потенційних загроз і супутніх їм ризиків, у результаті чого виникло поняття «корпоративні ризики». Корпоративні ризики повинні враховувати в плануванні і прогнозуванні своєї діяльності компанії, корпорації та інші суб'єкти

Таблиця 1. Класифікація ризиків за видами

\begin{tabular}{|c|c|c|}
\hline Вид ризику & Зміст, причини виникнення & Методи управління ризиком \\
\hline Кредитний & $\begin{array}{c}\text { Несплата позичальником основного боргу та } \\
\text { відсотків, належних кредитору, у встановле- } \\
\text { ний термін. Ризик полягає в нездатності або } \\
\text { небажанні позичальника діяти відповідно до } \\
\text { умов укладеного договору, на основі якого } \\
\text { надавалися гроші. }\end{array}$ & $\begin{array}{c}\text { Адміністративні: вироблення чітких вимог до формаль- } \\
\text { них ознак документів, наданих контрагентами за угода- } \\
\text { ми, а також до торгових майданчиків, через які прово- } \\
\text { дяться угоди з цінними паперами. } \\
\text { Економічні: встановлення граничного обсягу боргових } \\
\text { інструментів одного емітента, які можуть бути прийняті } \\
\text { компанією на власну позицію; на одного позичальника; } \\
\text { встановлення переліку контрагентів, з якими компанія } \\
\text { може укладати угоди на зразок РЕПО (repurchase } \\
\text { agreетеnt, угода перепродажу); переліку цінних паперів, } \\
\text { які приймаються; встановлення терміновості угод; вста- } \\
\text { новлення дисконтів, ліміту залишку грошових коштів } \\
\text { на розрахункових рахунках господарюючого суб'єкта в } \\
\text { кредитній установі. }\end{array}$ \\
\hline Ліквідності & $\begin{array}{c}\text { Нездатність компанією повністю або } \\
\text { частково виконувати свої зобов'язання і } \\
\text { фінансувати прийняті позиції з угод. Ризик } \\
\text { втрати ліквідності ринком системний, нело- } \\
\text { кальний. Причина виникнення - рішення, що } \\
\text { ухвалюються на рівні макроекономіки. }\end{array}$ & $\begin{array}{c}\text { Адміністративні: наявність процедур, які передбача- } \\
\text { ють попередній і поточний контроль під час підготовки } \\
\text { та виконання видаткових документів; наявність } \\
\text { формалізованої процедури роботи компанії з готівковими } \\
\text { коштами. } \\
\text { Економічні: наявність чітких алгоритмів ухвалення } \\
\text { управлінських рішень у разі виникнення загрози втра- } \\
\text { ти ліквідності; моніторинг стану ліквідності компанії; } \\
\text { наявність дієвих договорів на кредитні лінії і можливість } \\
\text { скористатися овердрафтом; встановлення лімітів за об- } \\
\text { сягом грошових коштів на розрахункових рахунках для } \\
\text { підтримки миттвої ліквідності. }\end{array}$ \\
\hline
\end{tabular}


Таблиця 1 (закінчення)

\begin{tabular}{|c|c|c|}
\hline Вид ризику & Зміст, причини виникнення & Методи управління ризиком \\
\hline Процентний & $\begin{array}{c}\text { Ризик погіршення фінансового стану } \\
\text { компанії внаслідок несприятливих змін } \\
\text { ринкових процентних ставок. Містить ри- } \\
\text { зик переоцінки - виникає через розрив у } \\
\text { терміновості активів і пасивів, та базисний } \\
\text { ризик - недосконалість кореляції під час } \\
\text { коригування сплачуваних та отримуваних } \\
\text { відсотків із низки інструментів, які за інших } \\
\text { рівних умов мають схожі цінові характери- } \\
\text { стики. }\end{array}$ & $\begin{array}{c}\text { Адміністративні: наявність процедур, які передбачають } \\
\text { попередній і поточний контроль укладених договорів із } \\
\text { розміщення коштів компанії та дають своєчасно ухвалю- } \\
\text { вати рішення про припинення дії договорів. } \\
\text { Економічні: встановлення системи лімітів на } \\
\text { використовувані компанією інструменти з фіксованою } \\
\text { прибутковістю; встановлення прийнятного рівня } \\
\text { кореляції за прогнозу одержуваного і сплачуваного про- } \\
\text { центного доходу; встановлення вимог до умов угод, } \\
\text { пов’язаних із можливістю перегляду процентних ставок. }\end{array}$ \\
\hline Ринковий & $\begin{array}{c}\text { Ризики виникнення у компанії фінансових } \\
\text { втрат унаслідок зміни ринкової вартості } \\
\text { торгового портфеля, що містить фінансові } \\
\text { інструменти, які мають ринкову вартість і } \\
\text { придбані з метою подальшого перепродажу. }\end{array}$ & $\begin{array}{c}\text { Адміністративні: наявність затверджених процедур } \\
\text { контролю та моніторингу діяльності компанії на ринку } \\
\text { цінних паперів. } \\
\text { Економічні: для ринку цінних паперів (встановлення } \\
\text { переліку емітентів, цінні папери яких можуть купува- } \\
\text { тися у власний портфель (інвестиційний або торговий); } \\
\text { розподіл портфеля на торговельний (спекулятивний) } \\
\text { та інвестиційний; для грошового ринку (встановлен- } \\
\text { ня переліку валют, у яких проводяться спекулятивні } \\
\text { операції; встановлення лімітів на обсяги операцій; вста- } \\
\text { новлення рівнів stop-loss і take-рrofit для операцій на } \\
\text { грошовому ринку). }\end{array}$ \\
\hline Операційний & $\begin{array}{c}\text { Ризик фінансових втрат унаслідок нена- } \\
\text { лежного функціонування процедур вико- } \\
\text { нання операцій та управлінських систем } \\
\text { компанії, пов’язаних із недосконалістю } \\
\text { системи внутрішнього контролю, помилками } \\
\text { комп’ютерних систем, помилками (зокрема, } \\
\text { шахрайством) персоналу, неадекватними } \\
\text { процедурами діяльності. Базельський комітет } \\
\text { рекомендує вносити юридичний ризик у } \\
\text { операційний. }\end{array}$ & $\begin{array}{c}\text { Адміністративні: структурування всіх бізнес-процесів } \\
\text { і процесів обробки інформації, закріплення функцій } \\
\text { за структурними підрозділами; розмежування } \\
\text { відповідальності під час ухвалення рішень із метою } \\
\text { створення інтегрованої вертикалі, що дає змогу будь-якої } \\
\text { миті визначити посадову особу, яка ухвалює рішення; } \\
\text { закріплення службових інструкцій за відповідними вико- } \\
\text { навцями; наявність затверджених алгоритмів поведінки } \\
\text { виконавців і ухвалення рішень менеджерами в нестан- } \\
\text { дартних ситуаціях. }\end{array}$ \\
\hline $\begin{array}{c}\text { Інші види } \\
\text { ризиків }\end{array}$ & $\begin{array}{c}\text { Ризики, що виникають унаслідок надмірної } \\
\text { концентрації: } \\
\text { активів / зобов’язань компанії; } \\
\text { країнових (регіональних) активів / } \\
\text { зобов'язань компанії; } \\
\text { галузевих активів / зобов’язань компанії; } \\
\text { певного виду операцій. } \\
\text { Системний ризик - ризик зміни політичної } \\
\text { ситуації, припинення функціонування } \\
\text { транснаціональних корпорацій, колапсу } \\
\text { банківської системи, природних катаклізмів. } \\
\text { Ризик втрати репутації компанією. } \\
\text { Юридичний ризик - ризик зміни поведінки } \\
\text { контрагента й отримання доходів компанією } \\
\text { за однієї і тієї ж операції залежно від типу } \\
\text { укладеного договору (наприклад, один і } \\
\text { той самий папір можна продати, уклавши з } \\
\text { клієнтом договір комісії або договір дору- } \\
\text { чення). } \\
\text { Податковий ризик - ризик погіршення } \\
\text { фінансового стану компанії в результаті } \\
\text { зміни режиму оподаткування. Мінімізується } \\
\text { постійним моніторингом податкового законо- } \\
\text { давства, створенням схем оптимізації бази. }\end{array}$ & $\begin{array}{c}\text { Адміністративні: ухвалення рішень щодо диверсифікації } \\
\text { бізнесу для всіх видів ризиків надмірної концентрації } \\
\text { активів / зобов’язань і певного виду операцій. } \\
\text { Економічні: встановлення і виконання встановлених } \\
\text { лімітів. } \\
\text { Системний ризик - постійний моніторинг ситуації. } \\
\text { Ризик втрати репутації компанією - удосконалення } \\
\text { корпоративної культури, договірної дисципліни. } \\
\text { Юридичний і податковий ризики - постійний моніторинг } \\
\text { чинної нормативно-правової бази, вдосконалення методів } \\
\text { оптимізації бази. }\end{array}$ \\
\hline
\end{tabular}


підприємницької діяльності (ринкові ризики, операційні ризики, кредитні ризики, політичні ризики тощо). Багато із цих ризиків можуть бути хеджованими залежно від галузі, у якій діє ТНК.

Корпоративний ризик - ймовірність відхилення від запланованих показників через помилки в корпоративному управлінні (конфлікт інтересів, помилки у визначенні бізнес-процесів, розподілі функціональних обов'язків тощо).

Управління ризиками компанії охоплює всі види сучасних ризиків, що супроводжують іiі діяльність, зокрема:

1) коливання товарних цін;

2) помилки в електронних системах управління або обробці даних;

3) проблеми у відносинах із постачальниками матеріалів і комплектовання, зі споживачами готової продукції;

4) порушення умов функціонування внаслідок політичних змін у суспільстві;

5) перешкоди в проведенні стратегічного планування та розвитку виробництва внаслідок вимушених технологічних змін;

6) зміни регулювальної політики держави;

7) надійність фінансових партнерів;

8) зниження рівня корпоративного управління.

Цим списком не закінчується весь перелік можливих ризиків. Наприклад, компанія «Microsoft» нарахувала 144 видів ризику, які загрожують передбачуваності їі доходів.

Утім, проблема хеджування ризиків великих бізнес-систем в умовах посилення конкуренції на товарних ринках і зміни політичного устрою світу, загалом, актуальна як ніколи. Якщо перелік прийнятих на страхування ризиків буде розширюватися, то ризики конкретної великої компанії можуть бути зібрані в один пакет і виставлені на страховий ринок. Такі відомі компанії страхового і перестрахового бізнесу, як AIG, Swiss Re, SCOR, Zurich Insurance Group та інші, здатні покласти на себе весь пакет цих ризиків.

Фінансовий ризик об’єднує такі категорії: корпоративний, систематичний і несистематичний ризики.

Управління корпоративним ризиком залежить від культурних цінностей фінансового менеджера; виникає як у межах тільки певного філіалу ТНК, так і загалом; управління здійснюється як за системного підходу, так і в межах структурних підрозділів; від якості горизонтального підпорядкування.

Систематичний ризик $є$ наслідком зовнішніх i неконтрольованих змінних, які не є галузевими чи специфічними і впливають на весь ринок. Систематичний ризик виникає як на внутрішньому ринку, так і на міжнародному; для нейтралізації ризику застосовується механізм здійснення операцій на фінансових ринках материнської компанії та їхніх зарубіжних філій; виникає можливість подвійного оподаткуван- ня; методом зниження є диверсифікація за допомогою створення філіалів у різних країнах; залежить від цінового контролю в межах певної національної економіки; захист від потенційних збитків та інфляції здійснюється шляхом переміщення діяльності в іншу країну; валютний і політичний режим - основні групи ризиків. Управління несистематичним ризиком здійснюється як централізовано, так і децентралізовано та його особливості пов'язані з внутрішньою структурою діяльності ТНК. Корпоративний і несистематичний ризики $€$ контрольованими для ТНК - внутрішніми, систематичні - зовнішніми, до яких необхідно пристосовуватися.

Ринкова капіталізація 100 провідних корпорацій за рік (з квітня 2018 року по березень 2019-го) становила рекордні \$21 трлн, про що свідчать дані рейтингу Global Top 100 companies, який щорічно складає PricewaterhouseCoopers (PwC). [3] Цьогоріч зростання капіталізації найбільших компаній світу становило $5 \%$, що нижче за темпи приросту в 2018-му (плюс $15 \%$ ). Переважно приріст відбувся завдяки американським компаніям. Ринкова капіталізація компаній із Китаю і Європи, навпаки, знизилася, тоді як торік вони демонстрували зростання. У десятці найбільших компаній за ринковою капіталізацією опинилися переважно представники технологічного сектору й онлайн-торгівлі. Трійка лідерів розподілилася так: SAUDI ARABIAN OIL, APPLE INC, MICROSOFT CORP. Крім того, уперше за сім років змінився лідер. Усі ці роки рейтинг очолювала Apple. Ось уже п’ятий рік поспіль компанії зі США займають більш ніж половину всього рейтингу Global Top 100 (54 компаніi). Їхня частка в загальносвітовому обсязі ринкової капіталізації становить 63 \%. Услід за США на другому місці за обсягом капіталізації компаній іде Китай, трійку лідерів замикає ЄС. Уперше в рейтинг потрапили компанії з Індії та Саудівської Аравії. Компаній iз Росії в рейтингу немає. Дані зображено в таблиці 2.

\section{ОБГОВОРЕННЯ ОТРИМАНИХ РЕЗУЛЬТАТІВ}

Наведемо особливості управлінських заходів регулювання ризику, які використовує ТНК, на відміну від компаній, що діють у межах однієї національної економіки:

1) стратегія зменшення ризику, яка полягає в тому, що компанія диверсифікує (зменшує ризик шляхом розпорошення діяльності між різними об'єктами вкладення), лімітує або застосовує метод хеджування;

2) стратегія утримання ризику, яку визначаємо тим, що вона пов'язана 3 формуванням внутрішніх резервів підприємства;

3) загальноприйняті стратегії та методи, деякі 3 яких є специфічними, адже передача ризику - це не тільки його трансфер страховій компанії, а й введення валютних застережень, обрання валюти ціни, платежу та інших інструментів. 
Таблиця 2. Рейтинг 20 найбільших глобальних компаній станом на 30/06/2020

\begin{tabular}{|c|c|c|c|c|c|c|}
\hline Назва компанії & $\begin{array}{c}\text { Місце } \\
\text { в рейтингу } \\
\text { станом на } \\
\mathbf{3 0 / 0 6 / 2 0 2 0}\end{array}$ & $\begin{array}{c}\text { Ринкова } \\
\text { капіталізація, } \\
\text { млрд дол. } \\
\text { США } \\
\text { (30/06/2020) }\end{array}$ & $\begin{array}{c}\text { Місце в } \\
\text { рейтингу } \\
\text { станом на } \\
\text { 31/12/2019 }\end{array}$ & $\begin{array}{c}\text { Ринкова } \\
\text { капіталізація, } \\
\text { млрд дол. } \\
\text { США } \\
\text { (31/12/2019) }\end{array}$ & Локація & Сектор \\
\hline SAUDI ARABIAN OIL & 1 & 1,741 & 1 & 1,879 & Saudi Arabia & Oil\&Gas \\
\hline APPLE INC & 2 & 1,568 & 2 & 1,305 & United States & Technology \\
\hline MICROSOFT CORP & 3 & 1,505 & 3 & 1,203 & United States & Technology \\
\hline AMAZON.COM INC & 4 & 1,337 & 5 & 916 & United States & $\begin{array}{l}\text { Consumer } \\
\text { Services }\end{array}$ \\
\hline ALPHABET INC-A & 5 & 953 & 4 & 923 & United States & Technology \\
\hline FACEBOOK INC-A & 6 & 629 & 6 & 585 & United States & Technology \\
\hline TENCENT & 7 & 599 & 9 & 461 & Mainland China & Technology \\
\hline ALIBABA GRP-ADR & 8 & 577 & 7 & 569 & Mainland China & $\begin{array}{l}\text { Consumer } \\
\text { Services }\end{array}$ \\
\hline BERKSHIRE HATH-A & 9 & 430 & 8 & 554 & United States & Financials \\
\hline VISA INC-CLASS A & 10 & 372 & 12 & 370 & United States & Financials \\
\hline JOHNSON\&JOHNSON & 11 & 366 & 11 & 384 & United States & Health Care \\
\hline WALMART INC & 12 & 337 & 13 & 337 & United States & $\begin{array}{c}\text { Consumer } \\
\text { Services }\end{array}$ \\
\hline NESTLE SA-REG & 13 & 328 & 14 & 323 & Switzerland & $\begin{array}{c}\text { Consumer } \\
\text { Goods }\end{array}$ \\
\hline ROCHE HLDG-GENUS & 14 & 300 & 23 & 279 & Switzerland & Health Care \\
\hline MASTERCARD INC-A & 15 & 294 & 17 & 301 & United States & Financials \\
\hline PROCTER\&GAMBLE & 16 & 291 & 16 & 311 & United States & $\begin{array}{l}\text { Consumer } \\
\text { Services }\end{array}$ \\
\hline JPMORGAN CHASE & 17 & 283 & 10 & 437 & United States & Financials \\
\hline UNITEDHEALTH GRP & 18 & 275 & 24 & 279 & United States & Health Care \\
\hline TSMC & 19 & 274 & 21 & 287 & Taiwan & Technology \\
\hline HOME DEPOT INC & 20 & 265 & 29 & 238 & United States & $\begin{array}{c}\text { Consumer } \\
\text { Goods }\end{array}$ \\
\hline
\end{tabular}

Джерело: згруповано автором за даними [3]

Отже, управління ризиками на рівні транснаціональної корпорації має як схожості, так і відмінності з управлінням на рівні звичайної компанії. Особливості фінансових ризиків ТНК перш за все пов'язані з їхньою інтерпретацією, класифікацією та застосовуваними методами. Дуже важливо мати кваліфікований управлінський персонал, досконало визначати та намагатися запобігати виникненню ризиків.

Операції між підрозділами ТНК, розташованими в різних країнах, являють собою істотну частину зовнішньоторговельних обігів і розрахунків навіть великих західних країн.

Глобалізація діяльності корпорацій дає їм змогу перекладати 3 країни в країну у своїх інтересах величезні ресурси. Конкретний прояв впливу ТНК на економіку тієї чи іншої країни залежить від економічної потужності суб'єктів відносин, положення філій і дочірніх компаній ТНК у країні перебування.

\section{ВИСНОВКИ}

Завдяки своій організаційній структурі ТНК вдалося міцно закріпитися в системі світового господарства. ТНК, володіючи величезними капіталами, проникли не тільки в економічне життя країн-партнерів, що спричиняє виникнення часткової (а іноді й повної) економічної залежності цих країн від певної групи корпорацій, але й у політичне життя, підтримуючи ті чи інші партії та рухи, адже політична ситуація в країні $\epsilon$ одним із головних ризиків, що загрожують існуванню ТНК в ній.

До засобів зниження ступеня ризику відносимо: уникнення ризику, утримання його, передачу ризику.

До способів зниження ступеня ризику відносимо: диверсифікацію, придбання додаткової інформації, лімітування, страхування, хеджування.

Обов'язки керівників полягають у виборі найбільш відповідних для компанії рішень. Одне з основних його завдань - оцінити ризик і звести його до мінімуму, щоб отримати максимальний прибуток у разі вдалої операції та мінімізувати втрати в разі невдалої операції. 


\section{REFERENCES}

[1] Ministry of Finance of Ukraine. Official web-portal. Retrieved from: https://index.minfin.com.ua/ua/economy/fdi.

[2] State Statistics Service of Ukraine. Official web-portal. Retrieved from: http://www.ukrstat.gov.ua.

[3] Global Top 100 companies by market capitalisation. PwC official web-site. Retrieved from: https://www.pwc.com/gx/en/ audit-services/publications/assets/global-top-100-companies-june-2020-update.pdf.

\section{СПИСОК ВИКОРИСТАНОї ЛІТЕРАТУРИ}

[1] Міністерство фінансів України. Офіційний вебпортал. URL: https://index.minfin.com.ua/ua/economy/fdi/ (дата звернення: 22.10.2020).

[2] Державна служба статистики України. Офіційний вебпортал. URL: http://www.ukrstat.gov.ua/ (дата звернення: 22.10.2020).

[3] Global Top 100 companies by market capitalisation. PwC official web-site. URL: https://www.pwc.com/gx/en/audit-services/ publications/assets/global-top-100-companies-june-2020-update.pdf (дата звернення: 22.10.2020).

(C) Н. В. Коваленко, І. В. Панасюк Дата надходження статті до редакції: 07.12.2020 Дата затвердження статті до друку: 15.12.2020 